\title{
$\underline{6}$
}

\section{EXCLUDING GOOD FAITH AND RESTRICTING DISCRETION}

Paul S. Davies

'Fairness has nothing to do with commercial contracts. The parties enter into them in a spirit of competitive co-operation, with a view to serving their own interest. Commercial parties can be most unfair and entirely unreasonable, if they can get away with it'. This robust view was recently expressed, extra-judicially, by Lord Sumption. ${ }^{1}$ Although controversial, ${ }^{2}$ it represents a traditional approach to commercial contracts that will resonate with many. Yet there appears to have been something of a shift in the commercial contracts which trouble the courts. ${ }^{3}$ Lord Goff (as he later became) once remarked that spot contracts on standard terms were the 'staple diet' of the Commercial Court. ${ }^{4}$ To a large extent that remains true, but there has been a marked increase in commercial litigation concerning what may loosely be termed 'joint ventures'. 5 Such contracts typically apply over a long period of time and require a degree of co-operation between the parties.

In the context of such long-term agreements, can a party still act in an entirely selfserving manner? This question has given rise to divergent answers and some confusion. As highlighted in the previous chapter, the ability of a party to act exclusively for its own best interests may be restricted by the terms of the contract. There has been much discussion both of implied duties of good faith in the performance of a contract, and, relatedly, of implied terms controlling the exercise of contractual powers. But the basis of such terms remains unclear: should the focus be upon terms implied in fact or terms implied at law? And are some restrictions based upon general doctrines of law, rather than implied terms?

This paper will first analyse the potential basis of implied terms which restrict a party's ability to act in a self-serving way. ${ }^{6}$ It is suggested that terms should generally be implied in fact rather than at law, and that the parties remain able to exclude 'good faith'. Freedom of contract demands that parties can control the extent of the obligations to which they consent.

However, it may be that some controls on the exercise of a power, for example, cannot be excluded. If so, the better justification is not that there are some mandatory

\footnotetext{
${ }^{1}$ Lord Sumption, 'A Question of Taste: The Supreme Court and the Interpretation of Contracts' [2017] OUCLJ $301,310$.

${ }^{2} \mathrm{cp}$ Sir George Leggatt, 'Contractual Duties of Good Faith' (Lecture to the Commercial Bar Association, 18 October 2016) [26]: 'I believe it is a mistake to see contracting as an essentially adversarial activity'.

${ }^{3} \mathrm{G}$ Leggatt, 'Negotiation in good faith: adapting to changing circumstances in contracts and English contract law' [2019] Journal of Business Law 104, 105-106.

${ }^{4} \mathrm{R}$ Goff, 'Commercial Contracts and the Commercial Court' [1984] LMCLQ 382, 386-387.

${ }^{5}$ This umbrella term covers a wide range of contracts: see generally I Hewitt, S Howley, J Parkes (eds), Hewitt on Joint Ventures 6th edn (Sweet \& Maxwell 2016).

${ }^{6}$ Good faith is, of course, not necessarily inconsistent with acting in a self-interested manner, but its invocation in the commercial context generally constrains one party's ability to do so: see below. Ideas of good faith and proper purposes may also constrain a party's ability to act out of reasons of spite, which are not necessarily selfinterested: see below.
} 
'universal terms ${ }^{77}$ in all contracts, but rather some doctrines which cannot be excluded for reasons of public policy, just as liability for fraud or illegal conduct cannot be excluded. It is suggested that parties should not be able to exercise a power for an 'improper purpose', and that the doctrine of 'fraud on a power' should be recognised more clearly in the contractual context. Yet the range of 'proper purposes' may be very wide as a result of the parties' agreement, with the effect that parties can still effectively act in a self-interested manner.

\section{Express restrictions on self-interested behaviour}

Parties can expressly provide for restrictions on their ability to act in a self-interested fashion. Sir George Leggatt has recently observed that ${ }^{8}$

it has become much more common to find in contracts that come before our courts clauses expressed in the language of 'best endeavours' or 'reasonable endeavours' or of obligations to act 'in good faith'. Twenty or thirty years ago it would, in my experience, have been unusual to find such language in a commercial contract. Now it is an everyday occurrence.

Fundamental concerns of party autonomy and freedom of contract mean that such terms should be enforced by a court.

One potential barrier to enforcement may be that the term is insufficiently certain for a court to conclude that a binding agreement has been formed. The foundations of this obstacle lie in the well-known hostility of Lord Ackner to a duty of 'good faith' in Walford $v$ Miles. ${ }^{9}$ However, Walford $v$ Miles is a controversial decision ${ }^{10}$ which concerned a potential duty to negotiate in good faith where a contract had not yet been concluded. Where a contract has already been agreed, courts have generally shown a willingness to enforce those terms.

For instance, in Petromec Inc v Petroleo Brasileiro SA, Longmore LJ enforced a clause to negotiate certain extra costs in good faith, and remarked that: ${ }^{11}$

It is not irrelevant that it is an express obligation which is part of a complex agreement drafted by City of London solicitors ... It would be a strong thing to declare unenforceable a clause into which the parties have deliberately and expressly entered ... To decide that it has 'no legal content' to use Lord Ackner's phrase would be for the law deliberately to defeat the reasonable expectations of honest men ....

Similarly, in Emirates Trading Agency LLC v Prime Mineral Exports Private Ltd, ${ }^{12}$ Teare $\mathrm{J}$ held that a clause that disputes should be settled 'by friendly discussion' was enforceable (and had been complied with). Moreover, in certain circumstances, the ISDA Master

\footnotetext{
${ }^{7}$ M Furmston. 'Universal Terms in Contract' in L Gullifer and S Vogenauer (eds), English and European Perspectives on Contract and Commercial Law: Essays in Honour of Hugh Beale (Hart 2014); see too J Paterson, 'Good Faith Duties in Contract Performance' [2014] OUCLJ 283.

${ }^{8}$ Leggatt, 'Negotiation in good faith' (n 3) 106.

${ }^{9}$ Walford $v$ Miles [1992] 2 AC 128.

${ }^{10}$ See recently Leggatt, 'Negotiation in good faith'(n 3) 104.

${ }^{11}$ Petromec Inc v Petroleo Brasileiro SA [2005] EWCA Civ 891, [2006] 1 Lloyd's Rep 161, [121].

${ }^{12}$ Emirates Trading Agency LLC v Prime Mineral Exports Private Ltd [2014] EWHC 2104 (Comm), [2015] 1 WLR 1145 .
} 
Agreement ${ }^{13}$ requires one party to calculate sums due from the counterparty, with that calculation to be undertaken in good faith. The courts have been very clear that they will seek to give effect to this obligation. ${ }^{14}$ This is welcome. Courts should not readily find that contractual terms are too uncertain to be binding. ${ }^{15}$ As Leggatt $\mathrm{J}$ observed in Astor Management AG $v$ Atalaya Mining plc, '[ $\mathrm{t}$ ]he role of the court in a commercial dispute is to give legal effect to what the parties have agreed, not to throw its hands in the air and refuse to do so because the parties have not made its task easy'. ${ }^{16}$

However, it should be noted that an express obligation to act in good faith is unlikely to be construed broadly. In Mid Essex Hospital Services NHS Trust $v$ Compass Group UK and Ireland Ltd (t/a Medirest) ${ }^{17}$ a clause of the contract provided that 'The Trust and the Contractor will co-operate with each other in good faith'. A question arose as to whether this applied to the general performance of the contract, or whether it applied more narrowly to two particular purposes, namely the 'transmission of information and instructions' and to enable the contracting party 'to derive the full benefit of the contract'. The latter interpretation was favoured. ${ }^{18}$ Beatson $\mathrm{LJ}$ insisted that a broad obligation to cooperate in good faith should not cut across other, more specific provisions, ${ }^{19}$ and that a narrower interpretation should be preferred. ${ }^{20}$

\section{Implied restrictions on self-interested behaviour}

If courts will give effect to express terms imposing a duty of good faith, then there is no reason why they should not give effect to implied terms with similar content. ${ }^{21}$ But the fact that well-advised commercial parties could have made express provision for good faith performance may mean that a court will be wary about implying such terms. ${ }^{22}$ It is not for the court to improve the contract made by the parties, or to rescue one party from its own bad bargain. ${ }^{23}$

\footnotetext{
${ }^{13}$ Published by the International Swaps and Derivatives Association. On 'reasonable endeavours', see too Little $v$ Courage (1995) 70 P \& CR 469 (CA) 476. However, the object of the endeavours must be sufficiently certain and there must be sufficient objective criteria by which to evaluate the reasonableness of the endeavours: Dany Lions Ltd v Bristol Cars Ltd [2014] EWHC 817, [2014] 2 All ER (Comm) 403. See also Berkeley Community Villages Ltd v Pullen [2007] EWHC 1330 (Ch), [2007] 3 EGLR 101 (Morgan J); CPC Group Ltd v Qatari Diar Real Estate Investment Co [2010] EWHC 1535 (Ch), [2010] CILL 2908 (Vos J).

${ }^{14}$ See eg Lehman Brothers International (Europe) v Lehman Brothers Finance SA [2013] EWCA Civ 188, [2014] 2 BCLC 451.

${ }^{15}$ cf Wells v Devani [2019] UKSC 4, [2019] 2 WLR 617.

${ }^{16}$ Astor Management AG v Atalaya Mining plc [2017] EWHC 425 (Comm), [2018] 1 All ER (Comm) 547 [64]

${ }^{17}$ Mid Essex Hospital Services NHS Trust $v$ Compass Group UK and Ireland Ltd (t/a Medirest) [2013] EWCA Civ 200.

18 ibid, [97]-[121], [148], and [149].

19 ibid, [154].

${ }^{20}$ See too Portsmouth City Council v Ensign Highways Ltd [2015] EWHC 1969 (TCC). This approach seems consistent with a 'stricter' approach to interpretation that now seems to be preferred to the more 'liberal' approach which had been favoured by Lord Hoffmann: see below.

${ }^{21}$ Yam Seng Pte Ltd v ITC Ltd [2013] EWHC 111 (QB), [2013] 1 All ER (Comm) 1321.

${ }^{22}$ cf Churchill Falls (Labrador) Corporation Limited v Hydro-Québec [2018] SCC 46.

${ }^{23}$ See generally PS Davies, 'Bad Bargains' [2019] CLP (forthcoming).
} 
Parties would therefore be well-advised to include express terms of good faith where desired. ${ }^{24}$ Problems can arise where the contract is silent. As Cromwell J observed in Bhasin v Hrynew, ${ }^{25}$

The jurisprudence is not always very clear about the source of the good faith obligations found in these cases. The categories of terms implied as a matter of law, terms implied as a matter of intention and terms arising as a matter of interpretation sometimes are blurred or even ignored, resulting in uncertainty and a lack of coherence at the level of principle.

The suggestion that a contract can be 'interpreted' such that it must be performed in good faith, even where there is no express provision for good faith in the written contract, relies upon a broad approach towards interpretation. Although favoured by Lord Hoffmann, ${ }^{26}$ it seems inconsistent with the most recent, leading guidance from the Supreme Court in Arnold v Britton, which emphasised the importance of interpreting the words deliberately chosen by the parties, rather than departing from their plain meaning by reference to the factual matrix. ${ }^{27}$ This stricter approach should be favoured.

Interpretation should be concerned with the express terms of the contract. ${ }^{28}$ Interpreting silence, on the other hand, is inherently ambiguous and prone to error. As a result, where the contract does not explicitly provide for a contract to be performed in good faith, or for a power to be exercised in a 'reasonable' manner, courts should not strain the boundaries of interpretation such that it engulfs implication. Where the contract is silent as to 'good faith' (or any other term) it can only be found to be part of the contract through implication. Strictly, that implied term would then need to be interpreted. As the Supreme Court insisted in Marks and Spencer plc v BNP Paribas Securities Services Trust Co (Jersey) $L t d$ the processes of interpretation and implication are best considered to be distinct. ${ }^{29}$ All terms have to be interpreted, but it is not inevitable that any terms have to be implied into an agreement. In a detailed commercial contract the usual inference of silence is that no term should be implied and the loss simply lies where it falls. ${ }^{30}$ A term should only be implied where it is necessary to do so. ${ }^{31}$

\footnotetext{
${ }^{24}$ eg E McKendrick, 'The Regulation of Long-term Contracts in English Law' in J Beatson and D Friedmann (eds), Good Faith and Fault in Contract Law (OUP, 1995) 305. See too eg Lymington Marina Ltd v Macnamara [2007] EWCA Civ 151, [2007] 2 All ER (Comm) 825 (Arden LJ).

${ }^{25}$ Bhasin v Hrynew [2014] SCC 71, [2014] 3 SCR 494 [52].

${ }^{26}$ eg Investors Compensation Scheme Ltd v West Bromwich Building Society [1998] 1 WLR 896; Chartbrook Ltd v Persimmon Homes Ltd [2009] UKHL 38, [2009] 1 AC 1101. See too Lord Hoffmann, 'Language and Lawyers' (2018) 134 LQR 553.

${ }^{27}$ Arnold v Britton [2015] UKSC 36, [2015] AC 1619.

${ }^{28}$ H Beale (ed), Chitty on Contracts 33rd edn (Sweet \& Maxwell 2018) accurately states that interpretation 'denotes the process ... by which a court arrives at the meaning to be given to the language used by the parties in the express terms of a written agreement' para 13-041.

${ }^{29}$ Marks and Spencer plc v BNP Paribas Securities Services Trust Co (Jersey) Ltd [2016] UKSC 72, [2016] AC 742. The distinction appears to have been blurred a little in Wells v Devani (n 15), although, importantly, that case did not concern a written contract (and nor did Yam Seng (n 21) or Al Nehayan v Kent [2017] EWHC 1347 (Ch)): PS Davies, 'Interpretation and Implication in the Supreme Court' (2019) 78 CLJ 267.

${ }^{30}$ See eg Philips Electronique Grand Public SA v British Sky Broadcasting Ltd [1995] EMLR 472 (Bingham MR).

${ }^{31}$ Whether in fact (following Marks and Spencer plc v BNP Paribas Securities Services Trust Co (Jersey) Ltd)) or at law (Liverpool v Irwin [1977] AC 239).
} 
If duties of good faith respond to the parties' intentions through the traditional, restrictive tests for implication in fact, then they are not particularly intrusive. ${ }^{32}$ However, between commercial parties, at least, a term of good faith should not readily be implied. It will often be the case that a contract is efficacious even without such an implied term. ${ }^{33}$ Moreover, if an officious bystander were to ask both parties: 'Is there also a term that the contract be performed in good faith?' the parties might not respond: 'Oh, of course!' but rather: 'What do you mean by good faith?' As a result, the 'officious bystander' test for implication would not be fulfilled. ${ }^{34}$

It is perhaps for this reason that in cases where a term has been implied in fact, judges have been more particular about the content of the implied term, rather than simply implying a general term of good faith. For example, in Yam Seng Pte Ltd v International Trade Corp $L t d,{ }^{35}$ the terms implied into the bargain were narrower and better-defined than a broad resort to 'good faith'. ${ }^{36}$ Indeed, the focus on an individual contract means that the implied term can be tailored to the particular circumstances of the case. Thus in Sheikh Tahnoon $v$ Kent Leggatt LJ again implied more precise and narrow terms than 'good faith' ${ }^{37}$ In Equitas Insurance Ltd v Municipal Mutual Insurance Ltd Males LJ described good faith as 'merely a label'; ${ }^{38}$ the content of implied duties can be defined more precisely within the broader umbrella of 'good faith'.

In any event, a term should only be implied in fact if necessary to do so. ${ }^{39}$ The burden lies on the party seeking to imply a term. Yet some decisions appear to reverse that burden and suggest that a term will be implied unless a party can show that it should not be. ${ }^{40}$ That seems inappropriate. In British Telecommunications Plc v Telefónica O2 UK Ltd, Lord Sumption said that 'it is well established that in the absence of very clear language to the contrary, a contractual discretion must be exercised in good faith and not arbitrarily or capriciously'. ${ }^{41}$ It is not clear whether Lord Sumption was considering an implied term to act in good faith, or whether he was considering a general doctrine such as 'fraud on a power',

\footnotetext{
${ }^{32}$ See PS Davies, 'The Basis of Contractual Duties of Good Faith' [2019] Journal of Commonwealth Law 1. They are sometimes said to be 'intrinsic' to the bargain rather than imposed by law: Mid Essex Hospital Services (n 17) [82] (Jackson LJ).

${ }^{33}$ Monde Petroleum SA v WesternZagros Ltd [2016] EWHC 1472 (Comm), [2017] 1 All ER (Comm) 1009 (this issue was not considered on appeal: [2018] EWCA Civ 25).

${ }^{34}$ Shirlaw v Southern Foundries Ltd [1939] 2 KB 206, 227 (MacKinnon LJ).

${ }^{35}$ Yam Seng (n 21).

${ }^{36}$ Namely a duty to not 'knowingly provide false information' on which the counterparty was likely to rely and a duty not to authorise the sale of relevant products in certain territories below the 'particular price': see Davies, 'The Basis of Good Faith' (n 32).

${ }^{37}$ Namely, that a party to a joint venture would not enter into negotiations to sell his interest or part of his interest in the companies which they jointly owned to a third party covertly and without informing the other beneficial owner, and a duty not to use his position as a shareholder of the companies to obtain a financial benefit for himself at the expense of the other: [176]; see Davies, 'The Basis of Good Faith' (n 32) 14-19. See too eg Bristol Groundschool Ltd v Whittingham [2014] EWHC 2145 (Ch); D\&G Cars Ltd v Essex Police Authority [2015] EWHC 226 (QB).

${ }^{38}$ Equitas Insurance Ltd v Municipal Mutual Insurance Ltd [2019] EWCA Civ 718 [116].

${ }^{39}$ eg Eastleigh BC v Town Quay Developments Ltd [2009] EWCA Civ 1391, [2010] 2 P\&CR 2 [30]-[39] (Arden LJ), Gan Insurance Co Ltd v Tai Ping Insurance Co Ltd (No 2) [2001] EWCA Civ 1047, [2001] 2 All ER (Comm) 299, [43]-[78] (Mance LJ), [97] (Staughton LJ).

${ }^{40}$ Below.

${ }^{41}$ British Telecommunications Plc v Telefónica O2 UK Ltd [2014] UKSC 42, [2014] 4 All ER 907 [37].
} 
considered below. If the latter, then it is suggested that it should not be excludable. ${ }^{42}$ If the former, then the initial presumption regarding implied terms should be that a term is not implied unless necessary; the burden is not placed on the other party to show that an implication is not necessary. If a term is to be implied without reference to the parties' intentions, then it is not a term implied in fact but rather a term implied at law.

Courts are, generally, rightly wary of exercising their powers to imply terms at law. ${ }^{43}$ Imposing terms upon parties in such a manner is highly intrusive. That is why the requirement that such terms be necessary rather than just reasonable should be taken seriously. However, there can be a tendency to define the type of contract at issue narrowly, and thereby blur the boundary between terms implied in fact and terms implied at law: ${ }^{44}$ if the type of contract essentially covers barely more than the particular contract at issue, then the distinction between a term implied at law and in fact is very thin indeed.

Examples of contracts where obligations of good faith have been implied at law often involve a power imbalance between the contracting parties, such as that which arises in the contract of employment. ${ }^{45}$ Where there is no imbalance of power between commercial parties, it is less obvious that there is any need to imply a term of good faith. As regards spot contracts for the sale of commodities it would be very surprising to see an implied term of good faith, and such a term would serve little purpose: any breach of a term of good faith would invariably constitute a breach of a different term of the contract anyway. ${ }^{46}$ The debate is now focussed upon whether a term should be implied at law into 'relational contracts' ${ }^{47}$

In Monde Petroleum, Richard Salter QC, sitting as a Deputy High Court judge, was 'clear that the mere fact that a contract is a long-term or relational one is not, of itself, enough to justify such an implication'. ${ }^{48}$ Such an approach should be supported. After all, some longterm contracts may be zero-sum rather than mutually beneficial, ${ }^{49}$ and it might be doubted

\footnotetext{
42 Below.

${ }^{43}$ After all, unelected judges do not have the democratic legitimacy of Parliament when deciding that all contracts of a certain type should include a particular implied term.

${ }^{44}$ cf Scally v Southern Health and Social Services Board [1992] 1 AC 294.

${ }^{45} \mathrm{eg}$ Malik v Bank of Credit and Commerce International SA (in liquidation) [1998] AC 20.

${ }^{46}$ cf Bhasin (n 25) [60].

${ }^{47}$ However, it should be noted that if the duty of good faith consists only of the duty to act honestly and fidelity to the terms of the contract, then it may be difficult ultimately to justify its restriction to 'relational' contracts: see.below. It has been said that terms can be implied into 'commercial contracts', but the boundaries of that notion seem even more problematic than 'relational contracts': Cavendish Square Holding BV v Makdessi [2015] UKSC 67, [2016] AC 1172 [168] (Lord Mance); cf JML Direct Ltd v Freesat UK Ltd [2010] EWCA Civ 34 [14] (Blair J). The restriction to types of contract seems to have been ignored in Australia where there is evidence of the courts implying terms in law outside such common relationships: see, eg, Vodafone Pacific Ltd $v$ Mobile Innovations Ltd [2004] NSWCA 15 [125], [189]; Burger King Corp v Hungry Jack's Pty Ltd (2001) NSWCA 187 [159], [164]; Alcatel Australia Ltd v Scarcella (1998) 44 NSWLR 349, 369; cf Renard Constructions (ME) Pty Ltd v Minister of Public Works (1992) 26 NSWLR 234, 263, where Priestley JA referred to a 'hybrid' between implied terms in fact and in law; and see generally, E Peden, Good Faith in the Performance of Contracts (Butterworths 2003), Ch 6.

${ }^{48}$ Monde Petroleum SA v WesternZagros Ltd [250] (not considered on appeal: [2018] EWCA Civ 25).

${ }^{49}$ eg Property Alliance Group Ltd $v$ The Royal Bank of Scotland Plc [2018] EWCA Civ 355, [2018] 1 WLR 3529 .
} 
whether the concept of 'relational contracts' is sufficiently definite to constitute a nominate category of contracts; ${ }^{50}$ some contracts will exhibit more 'relationality' than others.

Nevertheless, there appears to have been a drift towards accepting a category of 'relational contracts' into which terms of good faith will be implied as a matter of law. This is very recent, and its utility doubtful. In Yam Seng, Leggatt J doubted whether English law had reached the stage where it would be 'ready to recognise a requirement of good faith as a duty implied by law, even as a default rule, into all commercial contracts' ${ }^{51}$ But in Al Nehayan $v$ Kent Leggatt LJ thought that 'relational contracts' was a category of contract: ${ }^{52}$

I drew attention to a category of contract in which the parties are committed to collaborating with each other, typically on a long term basis, in ways which respect the spirit and objectives of their venture but which they have not tried to specify, and which it may be impossible to specify, exhaustively in a written contract. Such 'relational' contracts involve trust and confidence but of a different kind from that involved in fiduciary relationships. The trust is not in the loyal subordination by one party of its own interests to those of another. It is trust that the other party will act with integrity and in a spirit of cooperation. The legitimate expectations which the law should protect in relationships of this kind are embodied in the normative standard of good faith.

Leggatt LJ went on to hold that 'the nature of the contract as a relational contract implicitly requires (in the absence of a contrary indication) treating it as involving an obligation of good faith. ${ }^{53}$ However, it was not necessary to rely upon a term implied at law in Kent: Leggatt LJ also held that a term could be implied in fact. ${ }^{54}$

Al Nehayan $v$ Kent was an initial sign that the term implied in fact is 'hardening'55 into a term implied at law into relational contracts. This has been fortified by Bates $v$ Post Office Ltd (No 3: Common Issues). ${ }^{56}$ The case involves claims brought by a large number of sub-postmasters against the Post Office regarding the operation of a computer system used for accounting. The litigation between the parties is extensive and 'bitterly contested' ${ }^{57}$ However, in this decision Fraser J did not decide whether the contracts between the Post Office and sub-postmasters had in fact been breached, but rather determined preliminary 'Common Issues' between the parties, mainly regarding the nature and content of the contracts. As Fraser J said: ${ }^{58}$

The first Common Issue ... is whether the contracts ... are what is called 'relational contracts'.... In my judgment, it is certainly one of the most important issues.

\footnotetext{
${ }^{50}$ For further discussion, see eg H Collins, 'Is a Relational Contract a Legal Concept?' in S Degeling, J Edelman and J Goudkamp (eds), Contract in Commercial Law (Lawbook Co 2016).

${ }^{51}$ Yam Seng (n 21) [131]. cf Bhasin (n 25) [33]

${ }^{52}$ Yam Seng (n 21) [167].

53 ibid [174].

54 ibid [174].

${ }^{55}$ Leggatt, 'Contractual Duties of Good Faith' (n 2) [50].

${ }^{56}$ Bates v Post Office Ltd (No 3: Common Issues) [2019] EWHC 606 (QB).

57 ibid [10]; see too [2017] EWHC 2844 (QB), [2018] EWHC 2698 (QB), [2019] EWHC 871 (QB), [2019] EWHC 1373 (QB).

${ }^{58}$ Bates (n 56) [31].
} 
Fraser $\mathbf{J}$ went on to cite a number of cases to support his conclusion that 'the concept of relational contracts is an established one in English law'. ${ }^{59}$ However, none of the cases cited in support of this conclusion make it clear what the boundaries of a relational contract are. For example, in Amey Birmingham Highways Ltd v Birmingham City Council Jackson LJ 'refused to venture into those contentious issues' about whether 'relational contracts' are subject to special rules. ${ }^{60}$ Although he recognised that the contract at issue in the case was 'relational', no consequences appear to flow from that conclusion. Fraser J also cited Globe Motors v TRW Lucas Varity Electric Steering, but in the passage cited Beatson LJ made no reference to the language of 'relational contract' at all, ${ }^{61}$ which would be consistent with there being no 'nominate category' ${ }^{62}$ of 'relational contract'. Fraser J also relied upon the decision of the Court of Appeal in MSC Mediterranean Shipping Co v Cottonex Anstalt, ${ }^{63}$ despite the language of 'relational' appearing nowhere in the judgment, and the court's forceful rejection of a general duty of good faith in English law. ${ }^{64}$ Nevertheless, Fraser J said: 'It should be noted that Moore-Bick LJ did not say that there was no such concept [of good faith], but rather it was neither necessary nor desirable to resort to it in that case. I consider this as consistent with, and further support for, the concept of relational contracts in English law, that is to say those that have an implied duty of good faith'. ${ }^{65}$ This is surprising, and appears to go against the thrust of Moore-Bick LJ's robust, traditional approach in Cottonex Anstalt.

Admittedly, in D\&G Cars Ltd v Essex Police Authority, ${ }^{66}$ Dove $\mathrm{J}$ thought that the contract under consideration was 'a 'relational' contract par excellence'. And the notion of a 'relational' contract has also been invoked by Leggatt LJ in both Yam Seng and Al Nehayan v Kent. But in none of those cases was the labelling of the contract as 'relational' crucial to the implication of a term or the outcome of the case. Describing the contract as 'relational' helped to bolster the conclusions already reached, but the same outcomes could have been reached without the language of 'relational contracts'.

However, the decision of Fraser $\mathrm{J}$ in the Post Office litigation goes further. The judge held that terms of good faith should be implied at law because the contracts were relational contracts $^{67}$ and said: ${ }^{68}$

I consider the following characteristics are relevant as to whether a contract is a relational one or not:

1. There must be no specific express terms in the contract that prevents a duty of good faith being implied into the contract.

\footnotetext{
59 ibid [705].

${ }^{60}$ Amey Birmingham Highways Ltd v Birmingham City Council [2018] EWCA Civ 264, [2018] BLR 225 [92].

${ }^{61}$ Globe Motors v TRW Lucas Varity Electric Steering [2016] EWCA Civ 396, [2017] 1 All ER (Comm) 601.

${ }^{62}$ Collins, 'Legal Concept' (n 50) 38.

${ }^{63}$ MSC Mediterranean Shipping Co v Cottonex Anstalt [2016] EWCA Civ 789, [2017] 1 All ER (Comm) 483.

${ }^{64}$ eg ibid [45].

${ }^{65}$ Bates (n 56) [705] (emphasis in original).

${ }^{66}$ D\&G Cars Ltd v Essex Police Authority [2015] EWHC 226 (QB) [176].

${ }^{67}$ See eg Bates (n 56) [700].

68 ibid [725].
} 
2. The contract will be a long-term one, with the mutual intention of the parties being that there will be a long-term relationship.

3. The parties must intend that their respective roles be performed with integrity, and with fidelity to their bargain.

4. The parties will be committed to collaborating with one another in the performance of the contract.

5. The spirits and objectives of their venture may not be capable of being expressed exhaustively in a written contract.

6. They will each repose trust and confidence in one another, but of a different kind to that involved in fiduciary relationships.

7. The contract in question will involve a high degree of communication, co-operation and predictable performance based on mutual trust and confidence, and expectations of loyalty.

8. There may be a degree of significant investment by one party (or both) in the venture. This significant investment may be, in some cases, more accurately described as substantial financial commitment.

9. Exclusivity of the relationship may also be present.

I hesitate to describe this as an exhaustive list. No single one of the above list is determinative, with the exception of the first one. This is because if the express terms prevent the implication of a duty of good faith, then that will be the end of the matter. However, many of these characteristics will be found to be present where a contract is a relational one. In other cases on entirely different facts, it may be that there are other features which I have not identified above which are relevant to those cases.

This is not a particularly helpful approach when deciding whether a nominate category of 'relational contracts' should be recognised. All these characteristics may be relevant, but do not clearly define the contours of a 'relational contract'. After all, the nine 'relevant characteristics' of Fraser J are not necessary for there to be a relational contract: the 'spirit and objectives ... may not be capable' of being expressed in written terms (5), there 'may be' significant investment or financial commitment (8), and exclusivity 'may' be present (9). These all appear optional. The other characteristics also lack clarity. How 'longterm' should a contract be (2)? How can it be determined whether the parties are 'committed to collaborating' (4)? What sort of 'trust and confidence' is necessary, and how does it differ from a fiduciary relationship (6)? What constitutes a 'high degree of communication and predictable performance' (7)? The boundaries are very unclear.

It is perhaps telling that Fraser $\mathbf{J}$ thought it relevant that the "parties must intend that their respective roles be performed with integrity, and with fidelity to their bargain' in (3). If this is what the parties intend, then the relevant term is likely to satisfy the officious 
bystander test and should be implied in fact. There is no need to resort to the more intrusive notion of implication at law.

In any event, it would be misleading to say that (1) is determinative of there being a relational contract. If a duty of good faith is excluded, that would suggest, on the approach of Fraser $\mathrm{J}$, that there is not a relational contract. It does not provide a positive reason to find that a contract is relational.

In Interfoto, Bingham LJ noted that the law has 'developed solutions in response to demonstrated problems of unfairness' ${ }^{69}$ It is far from clear that there is a demonstrated problem of unfairness in this context. In any event, terms should only be implied at law into relational contracts once it is clear what a relational contract is. That type of contract must be readily discernible; otherwise there is a risk of inconsistency, incoherency, and the courts' intruding into the parties' bargain where it is not necessary to do so. Attempts to create a discrete category of relational contracts seems invariably problematic. ${ }^{70}$ Moreover, the risk of self-seeking or opportunistic behaviour may simply be priced in to the contract from the outset, and implying terms at law may disturb a careful equilibrium crafted by the parties in the terms of the contract. Since it is now clear that express terms of good faith will be given effect by the court, ${ }^{71}$ the need to imply such terms at law into contracts between well-advised sophisticated commercial parties is reduced. ${ }^{72}$ Commercial parties should be aware of their ability to regulate their own agreements and relationships, and should be encouraged to do so. The absence of express duties of good faith may well be deliberate. ${ }^{73}$ Courts should be wary of implying a term of good faith that was not expressly included - especially through implication at law rather than implication in fact.

\section{EXCLUDING TERMS RESTRICTING SELF-INTERESTED BEHAVIOUR}

Bates $v$ Post Office confirms that implied duties of good faith can be excluded, even if the term is implied at law rather than in fact. ${ }^{74}$ This possibility has recently been doubted ${ }^{75}$

\footnotetext{
${ }^{69}$ Interfoto Picture Library Ltd v Stiletto Visual Programmes Ltd [1989] QB 433, 439.

${ }^{70}$ A good, but nevertheless uncertain, attempt to provide a test for a 'relational contract' is made by Collins 'Legal Concept' (n 50) 55: 'First, there is a long-term business relationship that will provide sufficient pay-offs to both parties to continue with the relationship even through periods of considerable adversity. Second, obtaining the benefits of the business relationship will require adaptation, co-operation, and evolution of performance obligations, so that indeterminate implicit obligations of this kind must be central to the deal. Third, these implicit indeterminate obligations must be understood as arising not from general moral standards or norms of reciprocity such as honesty, but will be tailored to achieve what is necessary to secure the success of the venture. Business necessity in this context requires the acceptance of obligations derived from the general concepts of co-operation and loyalty or commitment to the project.' Even Professor Macneil 'did not support the claim that there is a class of contracts that can properly be described as relational': ibid 46.

${ }^{71}$ See above.

${ }^{72}$ E McKendrick, 'The Regulation of Long-term Contracts in English Law' in J Beatson and D Friedmann (eds), Good Faith and Fault in Contract Law (OUP 1995) 329-33.

${ }^{73}$ Davies, 'Bad Bargains' (n 23).

${ }^{74}$ See similarly eg Yam Seng (n 21) [149]. See too eg Vodaphone Pacific Ltd. V Mobile Innovations Ltd (NSWCA). $c f$ R Hooley, 'Controlling contractual discretion' (2013) 72 CLJ 65, 81-82.

${ }^{75}$ E Lim and C Chan, 'Problems with Wednesbury Unreasonableness in Contract Law: Lessons from Public Law’ (2019) 135 LQR 88, 103.
} 
but Bates is consistent with a long line of cases in insisting that there is no scope for a court to imply a term which is contrary to the express terms of the contract. ${ }^{76}$

Bates also provides support for the view that good faith includes duties beyond an obligation to act honestly. ${ }^{77}$ This explicitly departs from the view taken in Chitty, ${ }^{78}$ but is consistent with earlier decisions such as Yam Seng and Al Nehayan $v$ Kent. The uncertainty surrounding the content of an implied obligation of good faith is one reason why commercial parties are likely to be wary of it and may seek to exclude it.

One irony of Bates may be that whilst it appears, on its face, to expand the reach of good faith, in practice it could have the opposite effect in commercial contracts: well-advised parties might act on the court's recognition that express terms might prevent the implication of good faith and insist upon clauses excluding good faith. ${ }^{79}$ Such clauses may even become incorporated into a party's standard terms. The likelihood of this is perhaps increased if it is accepted that a term of good faith should be implied at law into 'relational contracts', and the parties are not sure whether their contract would be classified as 'relational'. Parties may be inclined to limit the terms that could apply regardless of their intentions, and instead take control of their agreement by ensuring that only the express terms of the contract be enforced. ${ }^{80}$

However, it may be that courts will be unwilling to countenance that duties of good faith can readily be excluded. ${ }^{81}$ For example, a broad 'entire agreement' clause that purports to exclude all implied terms may be interpreted narrowly such that implied duties of good faith are not excluded. In GEC Marconi Systems Pty v. BHP Information Technology Pty, for instance, Finn J said: 'I find arresting the suggestion that an entire agreement clause is of itself sufficient to constitute an 'express exclusion' of an implied duty of good faith and fair dealing where that implication would otherwise have been made by law. ${ }^{82}$ But it is not clear why duties of 'good faith' should be treated differently to any other implied term. An entire agreement clause - like any other term of the contract - should be interpreted according to its natural meaning, and the courts should be slow to depart from that. ${ }^{83}$

Nevertheless, Hogg has observed that ' $[\mathrm{t}]$ he preponderance of opinion is that entire agreement clauses will not exclude implied duties of good faith, this suggesting that a

\footnotetext{
${ }^{76}$ See eg Assenagon Asset Management SA v Irish Bank Resolution Corp Ltd [2012] EWHC 2090 (Ch), [2013] 1 All ER 495, [46] (Briggs J); Dymoke v Association for Dance Movement Psychotherapy UK Ltd [2019] EWHC 94 (QB) [60] (Popplewell J).

77 ، ... there is implied an obligation of good faith (which is also termed "fair dealing" in some of the cases). This means that the parties must refrain from conduct which in the relevant context would be regarded as commercially unacceptable by reasonable and honest people. An implied duty of good faith does not mean solely that the parties must be honest' Bates (n 56) [711]. See too eg Devon Commercial Property Ltd v Barnett [2019] EWHC 700 (Ch).

${ }^{78}$ Bates (n 56) [710], disapproving Beale, Chitty on Contracts (n 28) para 1-058.

${ }^{79}$ E Granger, 'Sweating Over an Implied Duty of Good Faith' [2013] LMCLQ 418, 424.

${ }^{80}$ See R Calnan, 'Controlling Contractual Interpretation' in this volume.

${ }^{81}$ cf O Lando and H Beale (eds), Principles of European Contract Law (OUP 2000) proposes a mandatory duty of good faith and fair dealing (art 1:201), a default duty to 'co-operate in order to give full effect to the contract' (art 1:202) and the binding quality of 'reasonable generally applicable usages' (art 1:105).

${ }^{82}$ EC Marconi Systems Pty v BHP Information Technology Pty [2003] FCA 50 at [922].

${ }^{83}$ See Arnold v Britton (n 27). cf Vodafone Pacific Ltd v Mobile Innovations Ltd (n 47).
} 
targeted exclusion might be successful' ${ }^{84}$ Yet there is no reason why 'targeted exclusions' in a commercial contract should not be enforced. As Lord Bingham recognised in HIH Casualty and General Insurance Limited v Chase Manhattan Bank (regarding fraudulent misrepresentation): ${ }^{85}$

if a party to a written contract seeks to exclude the ordinary consequences of fraudulent or dishonest misrepresentation ... such intention must be expressed in clear and unmistakable terms on the face of the contract

Some implied terms cannot be excluded as a result of legislation. ${ }^{86}$ But implied duties of good faith are not of the same nature. Indeed, if a commercial contract sets out the duties owed by the parties in a detailed manner then good faith may be impliedly excluded; express exclusion may be unnecessary. ${ }^{87}$

\section{Excluding a duty to perform the contract honestly}

The most difficult crunch point occurs when a party tries to exclude an implied term that a party perform the contract honestly. At first blush, this looks both unprincipled and impractical. ${ }^{88}$ After all, parties cannot exclude liability for fraud ${ }^{89}$ and it may, perhaps, damage a party's reputation if it seeks to exclude any term that it perform honestly. ${ }^{90}$ Nevertheless, given the expansive definition of dishonesty that has recently been favoured by the English courts, parties may try to exclude terms regarding honest performance. This is worth exploring further: if a promissory obligation to act honestly can be excluded, then it follows that all duties found under the banner of 'good faith' can be excluded.

Most objections to the exclusion of honesty rest upon a conception of honesty that is defined subjectively. ${ }^{91}$ But that is not how 'dishonesty' is generally understood in English law, ${ }^{92}$ and it now seems clear that a standard approach to dishonesty should be adopted throughout private law. ${ }^{93}$ Yet dishonesty remains a troubled concept. ${ }^{94}$ Honesty and dishonesty are essentially jury questions. ${ }^{95}$ In the most recent Supreme Court decision dealing with this issue, Lord Hughes said that 'dishonesty is by no means a defined concept. On the contrary, like the elephant, it is characterised more by recognition when encountered than by

\footnotetext{
${ }^{84}$ M Hogg, 'The Implication of Terms-in-Fact: Good Faith, Contextualism and Interpretation' (2017) 85 George Washington Law Review 1660, 1688.

${ }^{85}$ HIH Casualty and General Insurance Limited v Chase Manhattan Bank [2003] UKHL 6, [2003] 1 All ER (Comm) 349, [16].

${ }^{86}$ See eg Unfair Contract Terms Act 1977 s2.

${ }^{87}$ cf Mid Essex Hospital Services (n 17).

88 cf Plan B Trustees Ltd v Parker (No 2) [2013] WASC 216, (2013) 11 ASTLR 242 [232] (Edelman J).

${ }^{89}$ Standard Chartered Bank v Pakistan National Shipping Corpn and Others (Nos 2 and 4) [2002] UKHL 43, [2003] 1 AC 959 [22]; HIH (n 85) [5], [16]

${ }^{90}$ Yam Seng (n 21) [135], [149].

${ }^{91}$ Hooley adopts a subjective definition of honesty in arguing that honesty should be non-excludable, but 'parties retain the ability to contract out of any higher standard of behaviour': see eg Hooley, 'Controlling contractual discretion' (n 74) 81-82, 88; SNCB Holding v UBS AG [2012] EWHC 2044 (Comm) [72] (Cooke J).

${ }^{92}$ Ivey v Genting Casinos (UK) Ltd, trading as Crockfords [2017] UKSC 67, [2017] 3 WLR 1212.

93 ibid; Group Seven Limited v Notable Services LLP [2019] EWCA Civ 614 [57], [103] .

${ }^{94}$ For recent difficulties in the context of dishonest assistance, see Group Seven (n 93).

95 Ivey (n 92) [48]; B Hale, 'Dishonesty' [2019] Common Law World Review 5, 12-14. Nevertheless, in Bhasin (n 25) Cromwell J said that a duty of honesty 'is also clear and easy to apply': [80]. This does not appear to reflect the English experience.
} 
definition' ${ }^{96}$ The inability clearly to define dishonesty may be unsettling to commercial parties.

The best guidance seems to be that dishonesty incorporates an objective element: ${ }^{97}$ given what the defendant knew, would a reasonable person consider that defendant to be dishonest? A defendant may therefore be held to be dishonest even though he actually thought he was acting honestly. ${ }^{98}$ This could cause concern to commercial actors based in different countries who do not share a common cultural background. If, in good faith, they consider themselves to be acting honestly, they might be surprised nonetheless to be found to be in breach of an implied term to act honestly. In order to eliminate this risk, they may seek to exclude an implied term to act honestly, particularly after the decision of the Supreme Court in Ivey v Genting Casinos (UK) Ltd.

Phil Ivey is a professional gambler. He played Punto Banco at a casino in London and won $£ 7.7$ million. The casino refused to pay because it thought Ivey had cheated: Ivey had noticed that the casino's cards were marked and was able to exploit this through edge-sorting. The Supreme Court held that Ivey had breached an implied term not to cheat. But the Supreme Court further held, obiter, that Ivey had been dishonest, even though Ivey had plausible reasons for thinking that he was acting honestly: he did not touch the cards, the cards used were provided by the casino, and the pit manager agreed to all Ivey's requests. But because a reasonable person would have considered Ivey to be dishonest, he was held to be dishonest. This is hard on Ivey on the facts, and may cause some concern amongst commercial parties. Dishonesty is a tricky concept for the civil law. Whilst it may have a useful role in the criminal law as a jury question, in private law it can tend to be circular. ${ }^{99} \mathrm{In}$ Royal Brunei Airlines $v$ Tan, Lord Nicholls said that dishonesty 'means simply not acting as an honest person would in the circumstances'. ${ }^{100}$ This begs the question: what would an honest person have done? The answer appears to be: he would not have acted dishonestly. But this is clearly circular and does not further our understanding of dishonesty.

The next time a professional gambler wants to take advantage of any potential flaws in a casino's operation, they may try to exclude an implied term not to act dishonestly. It is suggested that they should be able to do so. This enhances the important principle of commercial certainty. It is unduly paternalistic not to allow the parties to agree to permit one party to do all they can to win. Of course, a casino may well not agree to such an exclusion, but if it does (in order to attract business, for instance) then the courts should be prepared to give effect to that clause. The same result might be reached by saying that because the parties have made it clear that 'cheating' is allowed, what the gambler does is no longer cheating, or dishonest, since the casino consents. ${ }^{101}$ But the outcome is the same.

Indeed, it is not obvious that Lord Bingham was invariably correct to say that ' $[p]$ arties entering into a commercial contract ... will assume the honesty and good faith of

\footnotetext{
${ }^{96}$ Ivey (n 92) [48].

${ }^{97}$ See too Yam Seng (n 21) [144]; Group Seven (n 93) 'simplicity' of two-stage test

98 As happened in Ivey (n 92). The second limb of $R v$ Ghosh [1982] QB 1053 no longer seems to apply: DPP $v$ Patterson [2017] EWHC 2820 (Admin).

99 PS Davies, Accessory Liability (Hart 2015) ch 4.

${ }^{100}$ Royal Brunei Airlines Sdn Bhd v Tan [1995] 2 AC 378 (PC) 389.

${ }^{101}$ cf Bhasin (n 25) [74], citing UCC (2012) § 1-302(b).
} 
the other; absent such an assumption they would not deal'. ${ }^{102}$ Parties may be forced to contract with each other as a result of circumstances beyond their control. If both parties do not trust each other, but are nevertheless willing to enter into a contract because they decide that that is the best solution for each, then it is fictional to say that they are entitled to expect honest conduct from the other if in fact they do not. ${ }^{103}$ The parties may need to contract with each other out of necessity, but if both parties are happy to proceed with the contract in a spirit of mistrust and always checking the other party's position, it is arguable that the law should not prohibit them from doing so. ${ }^{104}$

In any event, it is important to appreciate that allowing one party to exclude a term that the contract be performed honestly does not mean that a party could commit fraud with impunity. Rather, it means that any such fraud would not be a breach of contract. ${ }^{105}$ Instead, the innocent party would have to sue in the tort of deceit. This would affect the remedies available: the remedies for breach of contract and deceit are not the same. ${ }^{106}$ The remedies awarded for breach of a duty of good faith in Al Nehayan $v$ Kent reflected the contractual expectation measure rather than the tortious measure. But because alternative avenues for redress exist through deceit, it is unnecessary to insist upon a mandatory contractual term of honesty.

An English approach which favours a strong notion of freedom of contract is perhaps at odds with that recently adopted by the Supreme Court of Canada in Bhasin. Cromwell J thought that '[b]ecause the duty of honesty in contractual performance is a general doctrine of contract law that applies to all contracts, like unconscionability, the parties are not free to exclude it'. ${ }^{107}$ But it is not a term of the contract that a party will not act unconscionably. Rather, unconscionability operates as a general doctrine that may prevent a party from enforcing a contract, or allow the other party to rescind the agreement. It may be that honesty should operate in a similar manner. This is best explored in the context of restrictions on contractual powers.

\section{The exercise of contractual powers}

There has been a rise of cases insisting that contractual powers must be exercised honestly and not in an arbitrary, capricious or irrational way, ${ }^{108}$ which has sometimes been said to 'boil down' to a requirement of good faith. ${ }^{109}$ But the basis of such a restriction is

\footnotetext{
${ }^{102}$ HIH (n 85), above. See too D Campbell, 'Good Faith and the Ubiquity of the "Relational" Contract' (2014) 77 MLR 460, 485.

${ }^{103}$ For further discussion of the role of trust, see N McBride, Key Ideas in Contract Law (Hart 2017) ch 2. For consideration of further reasons why one party might consent to what appears to be an unbalanced contract, see H Collins, 'Discretionary Powers in Contracts' in D Campbell, H Collins and J Wightman (eds), Implicit Dimensions of Contracts: Discrete, Relational and Network Contracts (Hart 2003) 219, 226-31.

${ }^{104}$ See too Hogg, 'The Implication of Terms-in-Fact' (n 84) 1667.

105 See too J Carter and W Courtney, 'Good faith in contracts: is there an implied promise to act honestly?' (2016) 75 CLJ 608.

106 S Whittaker, 'Good Faith, Implied Terms and Commercial Contracts' (2013) 129 LQR 463, 466-467.

${ }^{107}$ Bhasin (n 25) [75].

${ }^{108}$ Most notably following Braganza v BP Shipping Ltd [2015] UKSC 17, [2015] 1 WLR 1661.

${ }^{109}$ Hooley, 'Controlling contractual discretion' (n 74) 66. However, Hooley here uses good faith 'in the sense that the party exercising the discretion must do so honestly, which is narrower than the definition favoured in
} 
again not clear. For example, it has been said that the controls may arise through construction or implication ${ }^{110}$ without clarifying which. The focus has generally been on implied terms, although there is lively debate about whether such terms are implied in fact or at law. ${ }^{111}$ It is suggested that it may be better to have regard to well-known cases in equity on 'fraud on a power' in order to introduce a non-excludable restriction on parties' ability to exercise contractual powers in a self-interested way. ${ }^{112}$ Any further restrictions should generally be based upon terms implied in fact.

In any event, it is suggested that reliance on public law concepts and cases, such as Associated Provincial Picture Houses Ltd $v$ Wednesbury Corporation, ${ }^{113}$ in the area of commercial contracts is unlikely to be helpful. ${ }^{114}$ The development of contract law in this area might mirror the experience of the equitable jurisdiction regarding control of discretionary powers. By the turn of the present century, English courts were flirting with the use of Wednesbury unreasonableness in the equitable jurisdiction, ${ }^{115}$ but this has now been staunchly criticised and firmly sidelined. In the Court of Appeal in Pitt v Holt, Mummery LJ said: ${ }^{116}$

... analogies with judicial review in public law are unhelpful and unnecessary. There is an elementary distinction between, on the one hand, the liability in private law of a fiduciary for breach of duty and, on the other hand, the availability of judicial review for the control of abuses of public power. There are surface similarities in the language of discretion and in the debates about the limits of discretionary power, but the contexts are so different that it is dangerous to develop the private law of fiduciaries by analogy with public law on curbing abuse of power. Judicial review in public law is concerned with the lawfulness of decisions and acts of public authorities to ensure that they are acting within the limits of a power usually set by statute. Breaches of duty in fiduciary law relate to discretionary dispositive powers privately entrusted to a fiduciary who has been selected to exercise the powers for the benefit of members within a designated class. The discretion of the fiduciary is not controlled by the court, which will not interfere with matters of judgment by the fiduciary. The only ground on which the court will review the exercise of the discretion is that of a breach of fiduciary duty. The underlying principles of fiduciary law and private property law are conceptually different from the public interest basis for reviewing the lawfulness of administrative action.

\footnotetext{
recent cases, such as Bates, above. See below. $f f$ M Bridge, 'The Exercise of Contractual Discretion' (2019) 135 LQR 227.

${ }^{110}$ Watson v Watchfinder.co.uk Ltd [2017] EWHC 1275 (Comm), [2017] Bus LR 1309 [102]; BHL v Leumi ABL Ltd [2017] EWHC 1871 (QB), [2017] 2 Lloyd's Rep 237 [40].

${ }^{111}$ cf Lim and Chan, 'Problems with Wednesbury Unreasonableness' (n 75) 102-103.

112 See similarly P Sales, 'Use of Powers for Proper Purposes in Private Law' (2020) 136 LQR (forthcoming).

${ }^{113}$ Associated Provincial Picture Houses Ltd v Wednesbury Corporation [1948] 1 KB 223.

${ }^{114}$ See eg Sales, 'Use of Powers' (n 112); Bridge, 'The Exercise of Contractual Discretion' (n 109); C

Himsworth, 'Transplanting irrationality from public to private law: Braganza v BP Shipping Ltd' (2019) 23(1)

Edinburgh Law Review 1; J Morgan, ‘Against Judicial Review of Discretionary Contractual Powers' [2008]

$L M C L Q 230$; J Morgan, 'Resisting Judicial Review of Discretionary Contractual Powers' [2015] LMCLQ 483.

${ }^{115}$ Scott $v$ National Trust for Places of Historic Interest or Natural Beauty [1998] 2 All ER 705; Breadner $v$

Granville-Grossman (2000) 2 ITELR 812, [2001] Ch 523; Edge v Pensions Ombudsman [1998] 2 All ER 547,

[1998] Ch 512. For judicial discussion, see Seng v Tuang [2012] SGCA 41 [59]-[64].

116 Pitt v Holt [2011] EWCA Civ 197, [2012] Ch 132 [235].
} 
These criticisms were approved by Lord Walker in the Supreme Court, who reiterated that any analogy with public law 'cannot be pressed too far'. ${ }^{117}$

This rejection of the public law analogy at anything other than a high level of abstraction is sensible. Various methods have been well-developed in equity for controlling discretions in an appropriate manner, and private law should properly focus its attention on these doctrines. Some could readily prove useful in the contractual sphere. In particular, the notion of 'fraud on a power', which ensures that powers are only validly exercised in pursuit of a proper purpose for which the power was granted, could profitably be exploited in contract law more generally.

The doctrine of fraud on a power is of very long-standing. ${ }^{118}$ It is sometimes also known as the 'proper purpose rule'. ${ }^{119}$ The nature of the rule was recently considered by Lord Sumption in Eclairs Group Ltd v JKX Oil \& Gas Plc: ${ }^{120}$

In Duke of Portland v Topham (1864) 11 HLC 32, 54 Lord Westbury LC stated the rule in these terms:

'that the donee, the appointor under the power, shall, at the time of the exercise of that power, and for any purpose for which it is used, act with good faith and sincerity, and with an entire and single view to the real purpose and object of the power, and not for the purpose of accomplishing or carrying into effect any bye or sinister object (I mean sinister in the sense of its being beyond the purpose and intent of the power) which he may desire to effect in the exercise of the power.'

The principle has nothing to do with fraud. As Lord Parker of Waddington observed in delivering the advice of the Privy Council in Vatcher v Paull [1915] AC 372, 378, it

'does not necessarily denote any conduct on the part of the appointor amounting to fraud in the common law meaning of the term or any conduct which could be properly termed dishonest or immoral. It merely means that the power has been exercised for a purpose, or with an intention, beyond the scope of or not justified by the instrument creating the power.'

The important point for present purposes is that the proper purpose rule is not concerned with excess of power by doing an act which is beyond the scope of the instrument creating it as a matter of construction or implication. It is concerned with abuse of power, by doing acts which are within its scope but done for an improper reason.

A number of points concerning the doctrine of fraud on a power should be noted that will be useful when considering how such a doctrine might apply in the contractual context.

\footnotetext{
117 Pitt v Holt [2013] UKSC 26, [2013] 2 AC 108 [11]. In the contractual context, see eg Lehman Brothers International (Europe) (In Administration) v Exxonmobil Financial Services BV [2016] EWHC 2699 (Comm); [2017] 2 All ER (Comm) 959 [287] (Blair J).

${ }^{118}$ See eg Lane v Page (1754) Amb 233; Aleyn v Belchier (1758) 1 Eden 132

${ }^{119}$ Eclairs Group Ltd v JKX Oil \& Gas Plc [2015] UKSC 71, [2016] 3 All ER 641 [15].

120 ibid [15].
} 
First, the doctrine of fraud on a power is distinct from requirements of good faith. A power may be exercised in good faith but for an improper purpose. ${ }^{121}$

Secondly, the doctrine applies to all powers. Admittedly, in Eclairs Lord Sumption said that ' $[t]$ he limitation of the power to its proper purpose derives from its fiduciary character', ${ }^{122}$ but it would be a mistake to consider that the power must be fiduciary in nature for the proper purpose rule to apply. Eclairs concerned the powers given to company directors, and should be understood in that context. It is clear that the proper purpose rule is not limited to fiduciary powers. ${ }^{123}$ In Free Church of Scotland v Overtoun Lord Lindley said that it was 'clear that there is a condition implied in ... instruments which create powers, namely, that the powers shall be used bonâ fide for the purposes for which they are conferred'. ${ }^{124}$ In Wong v Burt the New Zealand Court of Appeal sensibly observed that ' $[\mathrm{t}] \mathrm{he}$ notion of fraud on a power itself rests on the fundamental juristic principle that any form of authority may only be exercised for the purposes conferred, and in accordance with its terms. The principle is one of general application'. ${ }^{125}$ This opens up the possibility that it should apply to contractual powers too.

Thirdly, the doctrine of fraud on a power is a mandatory rule that cannot be excluded. It applies even if a power is given to the donee in their 'absolute discretion' or 'uncontrollable discretion'. ${ }^{126}$ Whilst it is possible to conceive of situations where a power may be exercised whimsically, ${ }^{127}$ it must still be exercised for a proper purpose. ${ }^{128}$

Fourthly, the basis of the proper purpose rule is not universally accepted. It is sometimes said to be simply a rule of construction. Yet often the language used in the instrument conferring the relevant power will be entirely silent as to the purposes sought to be secured through the power. There will be no relevant words to be interpreted when undertaking the process of ascertaining what the proper purposes are. Instead, reference must be made to the particular ends intended to be achieved. ${ }^{129}$ Of course, there may well be a degree of overlap between construction and the proper purposes rule; in the equitable context, both refer to the intention of the donor of the power. The intention of the donor when conferring the power is obviously important when determining the relevant proper purposes.

\footnotetext{
${ }^{121}$ See eg The Bell Group Ltd (in liquidation) v Westpac Banking Corporation (No 9) [2008] WASC 239 [4456] (Owen J). See too the separate provisions in the Companies Act 2006, s 171 (proper purpose rule) and s 172 (good faith). cf Magda Racynska 'Good Faiths and Contract Terms' in this volume.

${ }^{122}$ Eclairs (n 119) [39].

${ }^{123}$ Aleyn v Belchier 636-7; Pitt v Holt (SC) (n 117) [61]; re Crawshay [1948] Ch 123; Re Brook's Settlement [1968] 1 WLR 1661.

${ }^{124}$ Free Church of Scotland v Overtoun [1904] AC 515, 695. See too G Farwell, A Concise Treaties on Powers 3rd edn (Stevens and Sons 1916) 457: a 'person having a limited power, must exercise it bona fide for the end designed'.

${ }^{125}$ Wong v Burt [2005] 1 NZLR 91 [27].

${ }^{126}$ See eg In Re Gulbenkian's Settlement [1970] AC 508, 518.

${ }^{127}$ Re Wright [1920] 1 Ch 108, 118; PJC v ADC [2009] EWHC 1491 (Fam) [15], [19].

${ }^{128}$ The scope of the proper purpose rule is broad. It may well be that a trustee's duty to act in the best interests of his beneficiary, for example, is best considered to be one aspect of the proper purpose rule: Lord Nicholls, 'Trustees and Their Broader Community: Where Duty, Morality and Ethics Converge' (1995) 9 Trust Law International 71, 74; F\&C Alternative Investments (Holdings) Ltd v Barthelemy [2011] EWHC 1731 (Ch), [2012] Ch 613 [229].

${ }^{129}$ R Nolan, 'Controlling Fiduciary Power' (2009) 68 CLJ 292.
} 
However, Lord Sumption was clear in Eclairs that an implied term 'is not the basis of the proper purpose rule'. ${ }^{130}$ Instead:

' $[\mathrm{t}]$ he proper purpose rule is a principle by which equity controls the exercise of a fiduciary's powers in respects which are not, or not necessarily, determined by the instrument. Ascertaining the purpose of a power where the instrument is silent depends on an inference from the mischief of the provision conferring it, which is itself deduced from its express terms, from an analysis of their effect, and from the court's understanding of the business context'. ${ }^{131}$

The context will naturally be significant when determining the proper purpose rule. Some powers are conferred for only one particular purpose, and some for a much wider range of purposes. In the latter situation, there may be virtually no 'improper purposes' for which the power could be exercised. Nevertheless, the rule is potentially applicable to all powers. ${ }^{132}$ There is no 'gateway' issue for the proper purpose rule. This might be contrasted to the discussion about whether a contractual power counts as a 'discretion' which is amenable to the application of 'the Braganza duty'. ${ }^{133}$ Discretion is not a term of art, and trying to define it for the purposes of allowing in concepts from public law, for example, will invariably prove problematic. ${ }^{134}$ The key question is often whether a right to act in a particular way is priced into the contract; determining whether something is a 'discretion' is irrelevant to this issue, which can readily be accommodated within the concept of proper purposes.

Invoking the concept of 'purpose' in contract law is not novel. ${ }^{135}$ For example, in Hayes $v$ Willoughby Lord Sumption noted that in the law relating to contractual discretions it is important 'to limit the decision-maker to some relevant contractual purpose'. ${ }^{136}$ And in Arnold $v$ Britton, Lord Neuberger said that the 'overall purpose of the clause and the lease' should be borne in mind. ${ }^{137}$ This is consistent with the observation of Lord Wilberforce in Prenn $v$ Simmons that although pre-contractual negotiations should not be used in the interpretative process, 'the factual background known to the parties at or before the date of

\footnotetext{
${ }^{130}$ Eclairs (n 119) [30]. cp Sales, 'Use of Powers for Proper Purposes' (n 112).

${ }^{131}$ Eclairs (n 119) [30].

132 cf G Thomas, Thomas on Powers 2nd edn (OUP 2012) [11.76].

${ }^{133}$ Watson v Watchfinder.co.uk Ltd (n 110) [102] (HHJ David Waksman QC).

${ }^{134}$ Dyson LJ has said that discretion 'connotes the exercise of judgment in making choices' (Carty v Croydon London Borough Council [2005] EWCA Civ 19, [2005] 1 WLR 2312, [25]) and Rix LJ that 'When a contract allocates only to one party a power to make decisions under the contract which may have an effect on both parties' (Socimer International Bank Ltd v Standard Bank London Ltd [2008] EWCA Civ 116 [60]). Such dicta can clearly apply very broadly indeed. A further difficulty is that the word 'discretion' often appears in contractual terms creating seemingly absolute rights: 'absolute discretion', 'sole discretion', and so on. Yet, as Foxton has pointed out, 'The term 'absolute contractual right' is essentially conclusory, expressing, rather than explaining, the conclusion that the right is not subject to discretion obligations': D Foxton, 'A good faith goodbye? Good faith obligations and contractual termination rights' [2017] LMCLQ 360, 372. See similarly Equitas Insurance Ltd v Municipal Mutual Insurance Ltd [2019] EWCA Civ 718 [111]-[113] (Males LJ). ${ }^{135}$ See eg Weinberger v Inglis [1919] AC 606; Price v Bouch (1987) 53 P \& CR 257; Gan Insurance Co Ltd (n 39) [67]; Paragon Finance Plc v Nash [2001] EWCA Civ 1466, [2002] 2 All ER 248, 262.

136 [14], admittedly drawing an analogy with public law. See similarly the comments of Lord Sumption in British Telecommunications Plc (n 41) [37].

${ }^{137}$ Hayes $v$ Willoughby [2015] UKSC 36, [2015] AC 1619 [15].
} 
the contract, including evidence of the 'genesis' and objectively the 'aim' of the transaction' could be of assistance in deciding the meaning of a term. ${ }^{138}$

In Paragon Finance Plc v Nash, ${ }^{139}$ the lender had a discretion under the contract with a borrower to vary the interest rate. The Court of Appeal held that the power, if exercised, had to be for a proper purpose. Dyson LJ thought that '[a]n example of an improper purpose would be where the lender decided that the borrower was a nuisance (but had not been in breach of the terms of the agreement) and, wishing to get rid of him, raised the rate of interest to a level that it knew he could not afford to pay'. ${ }^{140}$ The discretion in that case was not given to the lender deliberately to force a borrower to default, but rather to reflect changes in the market, for instance.

In Watson $v$ Watchfinder.co.uk Ltd HHJ David Waksman QC thought it was necessary to establish 'what the 'target' of that discretion is, in the sense of what the decision-maker is meant to be considering when deciding whether or not to exercise it'. ${ }^{141}$ The 'target' of a discretion may be better expressed as a 'purpose'. In any event, as the judge observed, 'in many cases this is straightforward and stated as part of the discretion'. ${ }^{142}$ The context will also often be revealing. For example, a landlord who has a discretion whether or not to allow an assignment of a lease to a new tenant cannot refuse in order to inflict pain on the current tenant, which would be an improper purpose, but must instead consider the proper purpose of whether the assignee would be a suitable tenant. ${ }^{143}$ Of course, if the express language is silent as to purpose it may be more difficult to establish relevant proper purposes, but often this will be possible by reference to the factual matrix within which the term operates. ${ }^{144}$

An interesting recent example of the proper purposes rule being applied is the decision of the Court of Appeal in Property Alliance Group Ltd $v$ Royal Bank of Scotland Plc. ${ }^{145}$ The case involved a swap contract which included the following clause:

'The Borrower authorises the Bank from time to time to obtain an up to date Bank instructed and addressed professional valuation of all or any of the Charged Properties from a valuer/surveyor acceptable to the Bank and the Borrower shall meet the cost of any valuations obtained by the Bank provided that the Borrower shall not be liable for the cost of more than one valuation for each of the Charged Properties in any one calendar year other than a valuation obtained following the occurrence of an Event of Default.'

At first instance, Asplin J emphasised that, even after Braganza, the claimant must still show that the implication of any controls over the Bank's power to obtain a valuation must be

\footnotetext{
${ }^{138}$ Prenn v Simmons [1971] 1 WLR 1381. See too Chartbrook Ltd v Persimmon Homes Ltd [2009] UKHL 38; [2009] 1 AC 1101; A Robertson, ‘Purposive Contractual Interpretation' (2019) 39 Legal Studies 230. cf Excelsior Group Productions Ltd v Yorkshire Television Ltd [2009] EWHC 1751 (Comm), [25] (Flaux J).

${ }^{139}$ Finance Plc v Nash [2001] EWCA Civ 1466, [2002] 2 All ER 248. Discussed further below.

${ }^{140}$ Paragaon Finance Plc v Nash [2001] EWCA Civ 1466, [2002] 2 All ER 248 [31]. cf Paterson

${ }^{141}$ Watson v Watchfinder.co.uk Ltd (n 110) [105]. See too eg BHL v Leumi (n 110) [34].

142 ibid.

${ }^{143}$ See International Drilling Fluids Ltd v Louisville Investments (Uxbridge) Ltd [1986] Ch 513, 519-521; Bromley Park Garden Estates Ltd v Moss [1982] 1 WLR 1019.

144 eg BHL v Leumi (n 110) [34]-[36]. Of course, there will be difficult cases where views can reasonably differ: see eg recently British Airways Plc v Airways Pension Scheme Trustee Ltd [2018] EWCA Civ 1533.

${ }^{145}$ Property Alliance Group Ltd v Royal Bank of Scotland Plc [2018] EWCA Civ 355, [2018] 1 WLR 3529.
} 
necessary in order to make the contract work, and rejected any such limitations on the facts. This approach is appropriate when considering 'duties' of good faith, reasonableness, and so on. But the proper purposes rule must still apply. Indeed, the Court of Appeal differed from the trial judge and held that some fetters on the power to ask for a valuation were inherent. The Court of Appeal rightly emphasised that the Bank was able to exert the power in its own interests and did not need to balance such interests with those of the Borrower, but nonetheless held that it should 'be inferred that the parties intended the power ... to be exercised in pursuit of legitimate commercial aims rather than, say, to vex PAG maliciously'. ${ }^{146}$ This is a sensible application of the proper purposes rule, without explicitly using such language. The purposes are gleaned from the parties' intentions, and they may be broadly defined. Requiring a party to act in pursuit of legitimate commercial aims is not onerous and represents a suitably mild form of control.

A difficult example is Mid Essex Hospital Services NHS Trust v Compass Group UK and Ireland Ltd ( $t$ /a Medirest). ${ }^{147}$ The contract contained a mechanism under clause 5.8 whereby an NHS trust could award 'service failure points' from which it could calculate appropriate payment deductions for a catering company's performance failures. Jackson LJ said: ${ }^{148}$

'There is no justification for implying into clause 5.8 a term that the Trust will not act in an arbitrary, irrational or capricious manner. If the Trust awards more than the correct number of service failure points or deducts more than the correct amount from any monthly payment, then that is a breach of the express provisions of clause 5.8. There is no need for any implied term to regulate the operation of clause 5.8.'

The power to award points and deductions was clearly given to the trust for its own benefit in the event of defaults by the catering company. If the company failed to meet its obligations, then it could not be improper for the trust to award points and deductions.

It is helpful to distinguish the narrow scope of the proper purpose rule from more broad and intrusive implied terms that may restrict the exercise of a contractual discretion. It may be that there is a small, mandatory, inherent restriction that applies to all contracts in the form of an obligation to exercise a power for a proper purpose. But that does not invariably extend to a contractual obligation to consider all relevant factors and no irrelevant factors, or to act in a reasonable way. Such terms should not invariably be inserted into all contracts. For instance, in Hamsard 3147 Ltd (t/a Mini Mode Childrenswear) v Boots UK Ltd Norris J could 'readily accept that there will generally be an implied term not to do anything to frustrate the purpose of the contract' but thought that any restrictions beyond that would require extra justification. ${ }^{149}$

The proper purpose rule has been said very clearly not to rest upon an implied term, ${ }^{150}$ and should be considered mandatory. The proper purpose rule would then be similar to equitable doctrines such as unconscionability in that it would apply generally without being a term of the contract. This will affect the available remedies. Breach of a term entitles the

\footnotetext{
146 ibid [169].

${ }^{147}$ Mid Essex Hospital Services (n 17).

148 ibid [92].

${ }^{149}$ Hamsard 3147 Ltd (t/a Mini Mode Childrenswear) v Boots UK Ltd [2013] EWHC 3251 (Pat) [86].

${ }^{150}$ Eclairs (n 119).
} 
innocent party to damages, generally assessed by reference to its expectation loss. ${ }^{151} \mathrm{By}$ contrast, breach of a mandatory rule renders the exercise of the power invalid in some way, presumably rendering it void or voidable. ${ }^{152}$ And of course a mandatory rule cannot, by definition, be excluded: if the parties expressly wanted to exclude the proper purpose rule, they would not be able to do so. ${ }^{153}$

In any event, it is possible for the parties to agree to controls beyond the narrow ambit of the proper purposes rule. But such controls will generally need to be established either as express terms of the contract or terms implied in fact. And, as seen above, implication is not automatic. For example, in Gan Insurance Co Ltd v Tai Ping Insurance Co Ltd (No.2) Mance LJ observed that the 'authorities do not justify any automatic implication, whenever a contractual provision exists putting one party at the mercy of another's exercise of discretion' ${ }^{154}$ Careful consideration of the particular contract is required if a term is to be implied in fact.

\section{CONCLUSION}

The notion that commercial parties are under a duty to act in good faith deserves serious scrutiny. ${ }^{155}$ If commercial parties want such a duty to be incorporated into their contract, then they should be encouraged expressly to provide for it. ${ }^{156}$ And the courts should enforce such terms. But where the contract is silent about the need to act in good faith, then courts should generally only imply duties of good faith if they satisfy the stringent tests for implication of a term in fact. Terms should not be implied at law unless the category of contract at issue can be clearly defined. Whether there is room to imply a term will depend on the facts of a given case, but it is important to remember that 'an implication of a duty of good faith will only be possible where the language of the contract, viewed against its context, permits it' ${ }^{157}$ Duties of good faith - whether implied in fact or at law - can be

\footnotetext{
${ }^{151}$ Morris-Garner v One Step [2018] UKSC 20, [2019] AC 649. ${ }^{152}$ cf Pitt v Holt (SC) (n 117).

153 cf Mid Essex Hospital Services (n 17) [83] Jackson LJ: 'a term [that a party not exercise its discretion in an arbitrary, capricious or irrational manner] is extremely difficult to exclude, although I would not say it is utterly impossible to do so'.

${ }^{154}$ Gan Insurance Co Ltd (n 39) [62]. See too eg Eastleigh BC v Town Quay Developments Ltd [2009] EWCA Civ 1391, [30]; Watson v Watchfinder.co.uk Ltd (n 110) [102]; Myers v Kestrel [50]-[51]; Bridge, 'The Exercise of Contractual Discretion' (n 109).

155 Twenty years ago, Sir Thomas Bingham described good faith as ' $[\mathrm{t}]$ he most important contractual issue of our time': 'Foreword' in R Harrison, Good Faith in Sales (Sweet \& Maxwell 1997) vi. cf White \& Carter (Councils) Ltd v McGregor [1962] AC 413, 430 (Lord Reid): 'it never has been the law that a person is only entitled to enforce his contractual rights in a reasonable way and that a court will not support an attempt to enforce them in an unreasonable way.' See too more recently SNCB Holding v UBS AG [2012] EWHC 2044 (Comm) [93] (Cooke J); also J Steyn, 'The Role of Good Faith and Fair Dealing in Contract Law: A Hair-Shirt Philosophy?' (1991) 1 Denning Law Journal 131, 140.

${ }^{156}$ See too Gan Insurance Co Ltd (n 39) [99] (Staughton LJ): 'If the parties believe that the market would welcome the term proposed in this case, or any other term on the same topic, they have only to persuade the market to adopt it for the future. I wonder whether they would succeed.'

${ }^{157}$ Globe Motors Inc (n 61) [68] (Beatson LJ), relying on Carewatch Care Services Ltd v Focus Caring Services Ltd [2014] EWHC 2313 (Ch).
} 
excluded by the parties. This supports the parties' ability to control the content of the agreements they voluntarily enter into. It also helps to enhance commercial certainty. ${ }^{158}$

However, the desire for some control of parties' powers is understandable. The general, non-excludable doctrine of fraud on a power should provide limited controls on a party's ability to exercise (contractual) powers: a power must be exercised for a proper purpose. But that does not mean that there is a term in every contract that the parties act in good faith. If well-advised commercial parties wish particular duties of good faith to govern their relationship, they should expressly provide for such duties in their contracts.

${ }^{158}$ Morgan 'Against Judicial Review' (n 114) 236-239. cp Bhasin (n 25) [34] “"enhance rather than detract from commercial certainty” - seems optimistic. See Davies 'The Basis of Good Faith'(n 32). 